ism (see Social History 20:3 [October 1995]). Sewell noted that the cultural turn of the 1970s and 1980s can be seen in retrospect as an attack on the deterministic social science paradigms that were predominant in the western world after World War Two. Historians should claim victory in that battle, Sewell argued, and reengage with the material, physical realm of history. The distribution of wealth and the demands of work have always shaped history, but they have always done so in particular political and cultural fields.

\title{
The Continuing Relevance of Class
}

\section{Andrew Strouthous \\ Colchester Institute}

This one-day seminar, organized by the London Socialist Historians Group and the Seminar in Comparative Labour and Working Class History, took place on May 25, 1996, at the Institute of Historical Research in London. It was attended by a hundred historians, political economists, and social scientists.

Neville Kirk (Manchester Metropolitan University) gave the keynote lecture. He warned of the dangers of presentism and that the serious defeats suffered by the labor movements of the United States and Europe, the electoral victories of the Right, and the "seeming triumph" of the market have all served to trigger this tendency. Historians have a duty to reconstruct the past as accurately as possible, not to mention contemporary concerns; however, he stressed, such engagements must be based on dialogues between concept and evidence.

Though opening a conference on class, Kirk did not reject the historical importance of other categories of identity, especially race and gender. He agreed with Dorothy Thompson that any adequate study of identity involves the most careful attention to language. He shared David Roediger's view, however, that "debates about whether to give priority to race or class necessarily lead to a zero-sum game and dead-end debates whereby an increasing emphasis on one variable leads inexorably to a diminished emphasis on the other." In fact, according to Kirk, an engagement with the full complexities of the evidence can demonstrate that, in certain contexts and over stipulated periods of time, one form of identity can take precedence over others.

Kirk illustrated his claims primarily by exploring the increasing attack on the centrality of class in studies of British Chartism - in particular, revisionist "linguistic" interpretations of mid-nineteenth-century En- 
glish workers' mobilizations. This work, originated by Gareth Stedman Jones and endorsed and extended beyond Chartism by Patrick Joyce in Visions of the People (Cambridge, 1991) and James Vernon in Politics and the People (Cambridge, 1993), conceives that the Chartists' program, language, and political ideas did not express class consciousness. Though acknowledging that these scholars' methodology has several strengths, Kirk felt that these were outweighed by weaknesses. Chartism, he argued, was a "mass political movement, rooted in struggle and conflict, and not the finer points of language." Chartists mistrusted middle-class reformers who had betrayed workers by supporting the Reform Act of 1832 and by opposing trade unionism. Though varied, the Chartists' language actually betrays a shared class interest among workers and their "producerist" allies. The concept of "the people" was no longer that of the productive working and middle classes opposing the aristocracy; rather, it became redefined as the working-class movement. Language is important, Kirk confirmed, but it should not be separated from its specific historical context.

A lively discussion followed. Alex Callinicos (University of York) argued that Kirk needed a more precisely structured definition of class. $\mathrm{He}$ believed that the methodology Kirk borrowed from E.P. Thompson is open to misuse by the very people Kirk criticized. Carlo Morelli (London School of Economics) argued for a return to political economy, believing that socialist historians have ignored this aspect of their work. Others returned to the theme of class structure and to the need for "grand narratives" in working-class history.

A handful of workshops followed which, like Kirk's keynote, sought to parse the connections between class and other identities. Brian Kelly (Brandeis University), Peter Alexander (Oxford University), and Rick Halpern (University College, London) introduced a session on "Race and Class: Mine Workers in the United States and South Africa." Kelly's paper on labor organization in the Alabama coal fields from 1908 to 1922 demonstrated that, contrary to coal industry claims of black antiunionism, and contrary to black middle-class objections to the "white man's union," the United Mine Workers Union (UMW) was the bearer of a rich and vibrant tradition of interracialism in Alabama and represented a distinctive exception to the rest of institutional life in the state. This did not necessarily imply an absence of racial prejudice within the ranks of the UMW. Yet in spite of this, the union remained the best possibility for alleviating the exploitation and special grievances that black miners faced.

Peter Alexander compared miners in South Africa with those in the US South over a similar period. His paper investigated the reasons for differences in racial organization of unions in the two countries. Alexander argued that research into US mine workers can help explain why unions in South Africa failed to develop along interracial lines. In the discussion that followed, methods of work and wage payment, as well as the roles of 
community, gender, and the state, were considered in relation to the questions raised by the two papers.

In the workshop on "Class Relations and Political Transformation in Eastern Europe: Germany, 1989 and Poland, 1980-1996," participants argued that the role of workers in these events has been underestimated by mainstream commentators. Al Rainie (University of Hertfordshire), in his paper on the reconstruction of Cracow, stressed the irony that "free-market ideology" had heavily influenced workers' actions. Officials of Solidarity were decisive in pushing for privatization, rationalization, and new management. This has since led to mass redundancies, wage cuts, and longer hours-not the hoped-for higher standard of living. Rachael Walker (City University) argued that right-wing economists have completely misrepresented the reality of economic transformation in the former "Stalinist" countries. Success was claimed for free-market nostrums like "shock therapy," but figures that allegedly prove growth were only achieved by making comparisons with the worst possible years of economic performance. In reality, much of these countries' industrial bases were destroyed, and so far little of significance has taken their place. Rainie agreed for the most part with Walker's analysis, while claiming that there are one or two "cathedrals in the desert" - successful enterprises-to cite.

Other workshops featured Ellen Meiksens Wood (York University, Toronto) on "Political Theory and the Rise of Capitalism," John Saville (Hull University) on "Gareth Stedman Jones and the Languages of Class," and Geoffrey de Ste. Croix (Oxford University) on "Class' in Societies Ancient and Modern." At the end of the day the conference reconvened to discuss the work presented. Many felt that it showed that socialist scholars need not retreat from attacks from the Right and from postmodernists. It is necessary to engage their ideas, but the time for defensiveness is over, they believed; indeed, it is time to go on the offensive by developing projects reasserting the relevance of class, and, in particular, encouraging and developing younger students in the writing of socialist history in its broadest sense.

Note: The London Socialist Historians Group (LSHG) has produced a series of working papers, including "The Feminist Challenge to Socialist History"; "Oil, the State and Industrial Development in Post Revolutionary Iran"; and "The Language and Vision of Post 1848 Chartism." Further information about the working papers or the LSHG should be addressed to Keith Flett, 38 Mitchley Road, London N17 9HG, England; telephone 0181-885-5276. 